\title{
Corpo sem órgãos e a produção da singularidade: A construção da máquina de guerra nômade
}

\author{
Body without organs and the production of singularity: \\ The construction of the nomadic war machine
}

\section{Regina Schöpke*}

Universidade Estadual do Rio de Janeiro (UERJ), Rio de Janeiro, RJ, Brasil

\section{Resumo}

Este trabalho tem como objetivo central mostrar como o conceito de corpo sem órgãos, que apareceu, primeiramente, na obra de Antonin Artaud, e que será reativado por Gilles Deleuze e Félix Guattari, está diretamente associado à produção da máquina de guerra nômade. Neste aspecto, é preciso ir mais longe na compreensão do sentido vital, existencial e político deste que não é um conceito propriamente dito, mas um modo de ser, um modo de se produzir e de produzir a existência. "Não é uma noção, um conceito, mas antes uma prática, um conjunto de práticas", afirmam Deleuze e Guattari. Em um sentido bem estrito, trata-se da produção de um corpo mais pleno, mais vivo, mais intenso, um corpo de resistência para o desejo e para a própria vida, o que só é possível se

\footnotetext{
* RS: Doutora em Filosofia; e-mail: rschoepke@uol.com.br
} 
desconstruímos o corpo criado para servir docilmente aos poderes do campo social. Só que é aqui que reside o maior de todos os perigos: nem toda desconstrução se converte em criação de um corpo sem órgãos no sentido revolucionário. É preciso que a guerra vá além daquela que se trava contra os órgãos ou contra o organismo (que, aliás, se levada às últimas consequências, como sabia o próprio Artaud, significa simplesmente matar-se). A guerra é pela libertação da vida que foi aprisionada no homem e pelo próprio homem. É contra o niilismo, que nasce da opressão das forças vitais que transformou, por sua vez, nosso corpo e nossa razão em reféns dos poderes estabelecidos. Criar um corpo sem órgãos para si é já fazer parte de um devir nômade libertário, que é, antes de tudo, criador de novos modos de ser, de existir, de viver.

Palavras-chave: Deleuze. Guattari. CsO. Singularidade. Nomadismo.

\section{Abstract}

This work is mainly aimed to show how the concept of body without organs, which initially has appeared in the work of Antonin Artaud, and will be reactivated by Gilles Deleuze and Felix Guattari, It is directly associated with the production of the nomadic war machine. Considering this aspect, we need to go further to understand the vital sense, existential and political that it is not a concept itself, but a way of being, a way of producing and to produce existence. "It's not an idea, a concept, but rather a practice, a set of practices" says Deleuze and Guattari. In a restrict sense, it is the production of a fuller body, more alive, more intense, a resistance body to desire and to live itself, which is only possible to deconstruct the body created to serve meekly to the powers of the social field; but it is here that resides the greatest of all dangers: not all deconstruction becomes creation of a body without organs in the revolutionary sense. It needs to go beyond that the war being waged against the authorities or against the body (which, incidentally, if carried to its logical conclusion, as did the Artaud himself, simply meaning to kill themselves). The war is the liberation of life that was imprisoned in the man and the man himself. It is against nihilism born of oppression of the vital forces that transformed, in turn, our bodies and our reason into hostages of the established powers. To create a body without organs itself is part of a libertarian becoming nomadic, that is, first of all, creator of new ways of being, to exist, to live.

Keywords: Deleuze. Guattari. CsO. Singularity. Nomadism. 


\section{Introdução}

"Eu só poderia crer num Deus que soubesse dançar".

(Nietzsche)

Este trabalho parte do seguinte pressuposto: é preciso ir mais longe na compreensão do sentido vital, existencial e político do conceito de corpo sem órgãos, que, como sabemos, apareceu primeiramente na obra de Antonin Artaud ${ }^{1}$, sendo posteriormente reativado por Gilles Deleuze e Félix Guattari (sobretudo, no Anti-Édipo e no Mil Platôs). Não se trata de buscar uma definição no sentido clássico do termo. Tratase de partir dele ou de, com ele se agenciar para entendermos melhor o que significa a produção da máquina de guerra nômade, que nada mais é, segundo pensamos, que a produção da singularidade. Afinal, o $\mathrm{CsO}$ não é, propriamente falando, um conceito, mas um modo de ser, um modo de se produzir e de produzir a existência. Ele "não é uma noção, um conceito, mas antes uma prática, um conjunto de práticas", afirmam Deleuze e Guattari (2012, v.3, p. 12).

Em outras palavras, e num sentido bem estrito, trata-se da construção de um corpo mais pleno, mais vivo, mais intenso, um corpo de resistência para o desejo e para a própria vida. Só que isso não é possível sem antes desconstruirmos o corpo que foi criado para servir docilmente aos poderes do campo social. Eis porque o $\mathrm{CsO}$ aparece em Artaud como uma declaração de guerra: guerra contra os órgãos, guerra contra o corpo ordenado, organizado, guerra, na verdade, contra o organismo em sua disposição e significância social. Trata-se de um "grito orgânico" do homem contra toda transcendência opressora. Trata-se de uma rebelião do próprio ser, que deseja a todo custo libertar a vida que se encontra aprisionada nele.

Mas não nos enganemos: não se trata de dissolução ou autodestruição do corpo físico. Pelo contrário, segundo pensamos, é preciso

Foi na obra radiofônica intitulada Para acabar com o juízo de Deus, do ano de 1947, que Artaud declara guerra aos órgãos. Sobre o corpo sem órgãos, cf. Os escritos de Antonin Artaud, L\&PM editores, 1983. 
distinguir o que seria uma desconstrução ativa e afirmativa de uma desconstrução reativa e niilista. É claro que associar a ideia do nômade à do esquizo ajudou a confundir um pouco mais as coisas, mas é preciso entender que não se está falando da esquizofrenia em si, enquanto patologia clínica, mas apenas de um devir esquizo, que estaria presente em toda dimensão revolucionária. “O esquizo é alguém descodificado, desterritorializado" (DELEUZE, 1992, p. 35), é alguém que perdeu seus limites, seus contornos, é alguém que se abriu para "o fora". Não se pode dizer que o revolucionário seja um esquizo, mas que existe um processo esquizo na medida em que o nomadismo consiste exatamente numa contínua desterritorialização e reterritorialização. Aliás, é nisso que consiste efetivamente pensar: é estar sempre neste movimento, não sendo o dogmatismo nada além do que a própria sedentarização do pensamento.

Isso não significa que não se possa chegar a posições e ideias mais firmes; mas quer dizer que, mesmo elas, serão sempre colocadas em xeque. O problema da esquizofrenia, no entanto, e, no caso, do próprio Artaud, é que se perde exatamente este movimento de expansão e de contenção, ou de desterritorialização e reterritorialização. É por essa razão que não se consegue produzir um corpo sem órgãos pleno. Afinal, é a própria vida que termina por se perder no fora, é ela que é tragada pelas forças avassaladoras do devir que a invade. É que toda vida é já uma forma de expansão e contenção de forças; toda vida precisa de certo contorno e limite ou ela própria se esvai. No entanto, se ela é excessivamente contida e limitada, ela perde sua vitalidade e movimento, e é aí que a morte se instala.

Não é por outra razão que Deleuze e Guattari colocam para si próprios uma questão semelhante a que Burroughs se colocou a propósito das drogas: "será que é possível captar a potência da droga sem se drogar, sem se produzir como um farrapo humano?" (DELEUZE, 1992, p. 35). Ou seja, será que é possível fazer movimentos de desterritorialização ou, simplesmente, experimentar novas potências e intensidades sem precisar ser um drogado, um louco ou um pervertido? Como se abrir para o fora sem se perder completamente no caos? 
Aí está a grande questão com relação ao processo esquizo. Nunca se tratou, em Deleuze e Guattari, de uma apologia da esquizofrenia, das drogas ou de qualquer perversão, ainda que possa nos confundir o espaço dado por eles aos $\mathrm{CsO}$ dos masoquistas, dos drogados, esquizofrênicos, hipocondríacos, etc., no capítulo dedicado à criação do corpo sem órgãos, no Mil Platôs. É fato que eles ressaltam e, por vezes, até exaustivamente (o que levou alguns psiquiatras a criticá-los como romantizadores da loucura) as potências liberadoras de fluxos e de intensidades presentes nos processos dissociativos em geral, nas drogas ou mesmo em algumas perversões sexuais, mas não se trata de eleger como modelos estes corpos em processo de desconstrução; pelo contrário, fica bem claro que se tratam aí de corpos que se esvaziam ao invés de se preencherem, ou seja, não são estes os CsO plenos e revolucionários. É que esses corpos sempre acabam extrapolando os limites do que poderia ser uma experimentação legítima do corpo, exatamente porque lhes falta o domínio geral do processo. Acrescentamos, por nós, que, neste caso, o que lhes falta é exatamente a ação do pensamento. Sem a ação do pensamento, também não se pode criar um $\mathrm{CsO}$ pleno e poderoso, simplesmente porque o $\mathrm{CsO}$ é um ato de resistência profunda e não uma dissociação ou desconstrução puramente física.

O que interessa, no entanto, para Deleuze e Guattari, acerca das práticas destes corpos em desconstrução é que algo se passa neles; é que eles experimentam novos agenciamentos de forças, de fluxos, de intensidades, mas que podem, é claro, ser experimentados por outros meios, e meios "certamente melhores" (2012,v.3, p. 19). O fundamental, no entanto, para Deleuze e Guattari, é mostrar que a psicanálise entende muito mal esses processos. Não se trata de negação de si ou de autodestruição simplesmente, ao menos não primariamente. Trata-se, antes de tudo, de uma guerra feita contra o organismo, de um levante, de uma busca desesperada pelas intensidades que foram roubadas, que foram capturadas para servir a forças que não são as da vida. "O CsO grita: fizeram-me um organismo! dobraram-me indevidamente! roubaram meu corpo!" (Deleuze e Guattari, 2012, v.3, p. 25). É que o próprio corpo é arrancado de sua imanência para que se construa um organismo, um significado, um sujeito. 
Em todo caso, é preciso que se entenda que uma desconstrução demasiado grosseira e imprudente arrebata o corpo e o faz ser tragado por linhas e conexões que o destroem. Por isso, Deleuze e Guattari, voltando ao tema posteriormente, afirmarão: "Não dizemos que o revolucionário seja esquizo. Afirmamos que há um processo esquizo, de descodificação e de desterritorialização..." (DELEUZE, 1992, p. 36). E é apenas a atividade revolucionária que impede que isso se transforme em esquizofrenia (DELEUZE, 1992, p. 36), em dissipação total. Em todo caso, é aqui que a questão do $\mathrm{CsO}$ gera os seus maiores contrassensos. Por um lado, aparecem os críticos que entenderam o Anti-Édipo e o Mil Platôs como uma romantização da loucura; por outro, surgem também aqueles que se pensam revolucionários apenas por estarem fora dos padrões, mas não é o fato de ser esquizo, drogado ou mesmo homossexual, que faz de alguém revolucionário (DELEUZE, 1992, p. 20). O devir revolucionário está muito além dos indivíduos e dos grupos. Não basta pertencer a um grupo, não basta ser isso ou aquilo. A máquina de guerra é uma potência ativa e criadora; trata-se da recriação de si em um devir inumano ou "um devir universal animal", que não quer dizer tornar-se animal (até porque isso já somos). Trata-se antes de desfazer-se da ordem humana no corpo para encontrar nossas próprias zonas de intensidade, nossos grupos, ou seja, as populações e as espécies que nos habitam (DELEUZE, 1992, p. 20). Só assim é possível criar um $\mathrm{CsO}$ verdadeiramente pleno e revolucionário.

Quanto aos que não têm limites, os que não podem senão se entregar à uma desconstrução desesperada, estes nunca se constituirão plenamente. Não é por outra razão que toda linha de fuga, que, em princípio, é uma linha de vida possível, pode se transformar rapidamente em linha de morte. Sabemos que isso pode soar moral, mas não é de moral que falamos. Estamos falando aqui de fisiologia, de política e de potência de vida. O devir-revolucionário de Deleuze e Guattari, que não pode ser pensado sem a noção do nômade, colhida transversalmente da obra de Nietzsche, quer dizer algo bem mais específico: quer dizer tornar-se uma máquina de guerra em prol da vida, da sua afirmação, da multiplicação dos afetos, em benefício da alegria. Só esse pode ser chamado de $\mathrm{CsO}$ pleno. 
Como dizem Deleuze e Guattari, o próprio Artaud conhecia “os perigos de uma desestratificação demasiado brutal, imprudente. Artaud não para de enfrentar tudo isto e aí sucumbe" (2012, v.3, p. 30). É que Artaud sabia bem que matar o corpo não o libertaria, mas, ainda assim, não podia conter a sua própria dissolução, com a qual lutava desesperadamente também. Em outras palavras, a desconstrução ativa, revolucionária, implica em reverter a ordem que foi imposta ao corpo pelas máquinas abstratas do campo social, mas é preciso que o próprio corpo não se perca neste devir. Não se trata, então, de uma destruição da ordem simplesmente; trata-se muito mais de se chegar ao próprio cerne da produção do corpo, para então rearranjá-lo em novas conexões e agenciamentos. É isso que significa a produção de si mesmo.

Enfim, não sabemos quem conseguirá transpor todos os riscos e perigos desta desconstrução, mas sabemos que não se trata de nenhum convite à loucura e à devassidão. $\mathrm{O} \mathrm{CsO}$ diz respeito à reinvenção da própria vida, diz respeito à produção da singularidade, a produção de si mesmo. Esse tema já era o de Nietzsche, antes mesmo de ser de Artaud. Eis porque o caráter revolucionário do $\mathrm{CsO}$ não deixa de ser um prolongamento da guerra nietzschiana instaurada contra a metafísica e a moral. Sem isso, não há verdadeira transmutação no sentido nietzschiano, pois o que não se conseguiu fazer, propriamente falando, diriam Deleuze e Guattari, foi exatamente criar um corpo que seja ele próprio uma máquina de guerra, um corpo que sirva à vida, que sirva à produção de novos modos de ser, de existir, de viver, de amar...

\section{A produção do corpo dócil sedentário}

Para além da tirania que os poderes exercem sobre a vida, e para além mesmo de nossas fictícias sensações de estabilidade, segurança e permanência, o corpo age subterraneamente, exigindo o que lhe é de direto. Seria preciso - se fosse plenamente possível - fazer uma história do corpo que contemplasse, desde que o homem é homem, o seu massacre contínuo e metódico, bem como suas derivas para suportar o "peso da existência". Colocamos entre aspas propositadamente, 
porque tal ideia quase sempre traz implicitamente um juízo moral contra a própria vida, considerada dura e cruel em si mesma, ocultando que, por trás deste juízo, os homens têm, há milênios, submetido a vida a uma estrutura de poder perversa, onde a contenção de todos os seus fluxos e devires tem tornado a própria existência irrespirável. É assim que a vida acaba entrando em guerra contra o próprio ser que a nega. Não deixa de ser isso a guerra de Artaud contra o organismo.

É que, como diz Deleuze, ser homem é já uma forma de aprisionamento da vida. E remetendo a Nietzsche, ele diz: "o super-homem nunca quis dizer outra coisa: é no próprio homem que é preciso libertar a vida" (DELEUZE, 1987, p. 125). Sim, aqui Deleuze está em total consonância com Nietzsche ${ }^{2}$, a quem chama de nômade ${ }^{3}$, e não por uma licença poética, mas porque Nietzsche opera em seu pensamento por desterritorializações, tal como os verdadeiros nômades. E, tal como eles também, opera por reterritorializações, pois se há algo que se entende muito mal na ideia de um nomadismo do pensamento é supor que o próprio pensamento, ao se descentrar, mergulhe no caos e permaneça nele.

Sem dúvida, o próprio pensamento é já essa operação complexa de desterritorializações e reterritorializações (ou seja, o pensamento é nômade por excelência), e é neste sentido que ele se opõe, para Deleuze - e, antes disso, para Nietzsche e também para Bergson -, à razão clássica, cuja estrutura demasiado lógica não pode apreender os fluxos da vida sem paralisá-los, recortá-los, sem encerrá-los em conceitos demasiado rígidos, como já dizia o próprio Bergson (2006, p. 195).

Dizer, portanto, que o homem é já uma forma de aprisionar a vida, é dizer que ele se constitui nesta contenção máxima dos fluxos. Isso é ser "homem": uma forma de encerrar a vida fora e dentro de si mesmo, um desejo desesperado de conter todos os fluxos da existência, desejo de dominar todas as variáveis para se sentir no controle

2 "É preciso aniquilar a moral para libertar a vida" é uma frase, e também um clamor, de Nietzsche. Para ele, a vida foi encerrada pelo homem e no homem a partir de uma moral que se construiu avessa à vida; trata-se de uma moral niilista que se confunde com a própria história da humanidade.

3 Nietzsche é apresentado, por Deleuze, como aquele que fez do pensamento uma máquina de guerra, uma potência nômade. Sobre este ponto, cf. DELEUZE, G., "Nietzsche, o pensador nômade" in Nietzsche hoje, pp.66-67. 
absoluto da vida que, no entanto, está sempre a lhe escapar pelos dedos. É um medo tão incontrolável dos devires, das mudanças, de tudo aquilo que coloca em risco a estabilidade do seu mundo, que este medo se converte num medo inescapável do próprio existir. E aí não é só a morte, como derradeira dissolução, que aparece como apavorante; são as mudanças, os movimentos inerentes da própria existência, que produzem contínuas angústias e sofrimentos. Acaba-se, por fim, por rejeitar a própria vida.

É por isso que, para Nietzsche, a indisposição para com a vida, o juízo negativo que se tem sobre ela, é já efeito da diminuição das forças vitais, efeito de um adoecimento do corpo e do pensamento que, desde o início, se faz presente no homem. O normal é já essa condição doentia do homem (NIETZSCHE, 2009, III, 14), cuja diminuição das alegrias termina por desligar a vontade de seu poder de ação e, assim, é contra si mesma que a vontade se volta, tal como um animal selvagem que, aprisionado, vai aos poucos se despotencializando, até que a morte se torna uma alternativa melhor do que viver. Sim, afinal, o que é o niilismo senão a vontade esvaziada, a morte inscrita na carne, a morte já instalada na vida?

Decerto que, no homem, a morte não diz respeito apenas ao derradeiro instante onde o corpo perde todas as suas forças, mas existe como uma forma de transfundo sombrio, uma espécie de subterrâneo, de subsolo do próprio corpo vivo. E isso quer dizer apenas o seguinte: que, no homem, o estrangulamento da vida, o encerramento dela em nós, gera pulsões e desejos mortais, desejos que se voltam contra o próprio ser. Mas não se trata, como nos quer fazer pensar a psicanálise ${ }^{4}$, de um instinto de morte que coabita com a vida no âmago do ser. Não se tratam de dois princípios, de duas pulsões primárias básicas: uma de vida e outra de morte. O desprezo pela vida (que, no fundo, oculta um rancor pela sua finitude), o niilismo como a doença humana por

4 Segundo Freud - 0 que será, posteriormente, endossado por Lacan - existiria um dualismo primário nas próprias pulsões e desejos humanos, ou seja, existiriam dois instintos básicos primários: um instinto de vida (Eros) e um instinto de morte (Tanatos) e eles seriam responsáveis pela eterna luta entre querer viver e querer morrer. Mas, para Nietzsche - e, mais tarde para Wilhelm Reich, outro discípulo de Freud que rompeu com seu mestre - só existiria a vida e sua vontade de potência, de plenitude. A vontade de morte, o niilismo, seria já um sintoma do adoecimento, do enfraquecimento das forças vitais. 
excelência (NIETZSCHE, 2009, prólogo 5), uma forma de grande cansaço, é apenas consequência do enfraquecimento da própria vida, é parte já da construção e ordenação de um corpo útil, dócil e frágil, insensível e mortificado, que serve exclusivamente aos poderes estabelecidos que se expressam numa transcendência que nos gere a todos: a do Estado e de suas máquinas abstratas coercitivas e punitivas.

Sem dúvida, o corpo nunca teve tão em evidência quanto no nosso tempo. Nunca se falou tanto em saúde, beleza, alimentação, sexualidade, etc.; nunca se deu tanto valor às relações e a conduta que temos com nosso próprio corpo, o que, no entanto, está longe de ser uma libertação dele. Ao contrário, para Foucault, trata-se de uma nova forma de apoderação e sujeição do corpo e dos indivíduos implementadas na modernidade. Não se trata de conhecê-lo simplesmente, mas de conhecê-lo para melhor moldá-lo, rearranjá-lo e, assim, submetê-lo aos processos produtivos. É isso que Foucault chamou de sociedade disciplinar. "A disciplina fabrica assim corpos submissos e exercitados, corpos dóceis" (FOUCAULT, 1988, p. 127). Trata-se de uma verdadeira "maquinaria de poder que o esquadrinha, o desarticula e o recompõe" (Idem).

Esse homem, tal como o conhecemos hoje, é parte de uma invenção que se arrasta desde o século XVIII. E é neste processo de individuação e criação do corpo, que foram sendo partilhados e classificados os próprios homens em sãos ou doentes, normais ou anormais, à medida que eles serviam ou não aos poderes. Como dizia Foucault com relação aos novos poderes, eles já não operam mais com a repressão pesada do corpo ${ }^{5}$. Suas marcas tornaram-se cada vez mais sutis e mais inescapáveis também, pois se trata, no fim das contas, de uma operação de construção do corpo desejado a partir de dentro, a partir de sua própria interioridade. É lá, bem no íntimo de cada um, que o poder se estabelece e se realiza agora. E não sem o aporte da família, da escola,

5 Em Vigiar e punir, Foucault nos mostra como, em princípios do século XIX, o grande e cruel espetáculo das punições públicas, com direito a esquartejamentos, fogueiras etc, vai sendo substituído por uma ação que excluiu do castigo a encenação da dor. Esta, aliás, é retirada de cena só na aparência, pois se trata agora de interiorizá-la, se trata de atingir "a alma". Que 0 castigo agora possa ferir a alma e não mais o corpo. " 0 aparato da justiça punitiva tem que se ater, agora, a esta nova realidade, realidade incorporal". cf. pp.16-21. 
do quartel, do escritório... Trata-se de um investimento maciço dos poderes nos próprios desejos e, sobretudo, na produção de novos desejos.

Em outras palavras, falar do corpo, colocá-lo sob às luzes da ribalta, fazê-lo trabalhar em prol da realização de todos os seus desejos, e até ilimitadamente, é parte ainda desta apoderação. Ou seja, o corpo não é livre porque busca desesperadamente realizar todos os desejos. Ao contrário, ele pode ser ainda mais escravo, embora se precise entender num novo viés o próprio capitalismo. Não se trata de uma máquina produtora de consumidores passivos. Tudo aqui é produção, mesmo o consumo (DELEUZE E GUATTARI, 2004, p. 14). Neste caso, temos sido ativamente escravos (ou simplesmente colaboradores) desta grande máquina ou, como diria La Boétie, somos "servos voluntários", pelo menos até que libertemos nosso desejo das malhas dos poderes e nos recriemos. É isso que significa, em suma, criar um corpo sem órgãos para si. É isso que significa construir a máquina de guerra nômade. É isso que significa singularizar-se de verdade.

Sim, e o que é a máquina de guerra senão a própria construção da singularidade? E como se singularizar sem reorganizar as forças e as linhas intensivas de nosso ser? É de vida e de política que falamos aqui. Mas também de ética, da relação com o outro, com o mundo. Não foram, afinal, Deleuze e Guattari que elegeram a Ética de Espinosa como o grande livro do CsO (2012, v.3, p. 17)? O que é a máquina de guerra nômade senão o próprio devir revolucionário e suas forças libertárias atravessando o nosso mundo sedentário? Devir que chamamos de libertário, exatamente porque sua verdadeira guerra é pela vida, para libertá-la dos poderes que a tornam fraca e esquálida.

Em tudo e por tudo, esta é uma guerra que se trava primeiro contra nós mesmos, ou contra aquilo que, em nós, serve a estes poderes. Ou seja, não se produziu uma máquina de guerra se não se entrou em guerrilha consigo mesmo, contra os poderes que estão interiorizados em nós e que, sem perceber, o reproduzimos continuamente. Mas é nesta guerra que o corpo e o pensamento se arriscam e podem sucumbir. É que é preciso implodir o campo de significância dado (mas sem se destruir) e inventar novas maneiras pensar, de ser e de viver. É 
preciso ir além do niilismo e tomar a vida nas mãos, é preciso ser o esteta de si mesmo. É somente assim que a subjetividade criada para servir aos poderes começa a se diluir em prol da vida e da criação. Afinal, é quando o corpo se liberta que ele pode servir a novas forças; às forças criadoras da vida. Arte e pensamento em uníssono. Novos cantos para novos mundos. Novos usos para as mãos, para a boca, para os ouvidos, para o corpo.

\section{Corpo sem órgãos: a produção da máquina de guerra nômade}

O conceito de máquina de guerra nômade, tal como ele apareceu no "Tratado de Nomadologia", no Mil Platôs, diz respeito ao tipo de organização guerreira dos antigos aqueus, cuja principal característica era não estar submetido ao poder direto dos reis. Ou seja, a máquina de guerra vivia à parte do aparelho do Estado. E, mesmo quando ela mantinha relações com ele, eram sempre acordos temporários que não incluíam qualquer afinidade real com os signos do mundo sedentário, cuja estrutura foi sempre pautada numa verticalidade do poder, ou seja, numa hierarquia que se fundamenta na figura transcendente do Estado e do déspota que o representa.

A despeito de Deleuze e Guattari falarem em uma complementaridade, a verdade mesmo é que a esfera sedentária da realeza, gera um espaço estriado, codificado, hierarquizado, enquanto que no mundo dos "iguais" (assim eram chamados os guerreiros), trata-se de um espaço liso, sem estrias e estratificações, exatamente porque todos se encontram num mesmo plano de imanência, sem hierarquias. A oposição entre estes dois mundos é profunda, a despeito dos acordos temporários e mesmo sabendo que o nomadismo atravessa o sedentarismo e que um não existe sem o outro. Acontece que a máquina de guerra nômade tem seus próprios valores e vive fielmente dentro da sua ética de grupo, de bando, de tribo. É neste sentido que a máquina de guerra está para a imanência enquanto o aparelho de Estado está para a transcendência, bem como a imanência está para uma ética tanto quanto a transcendência está para a moral. Ou seja, a moral é vertical; a ética é 
horizontal. A moral é algo dado de cima para baixo, enquanto a ética é a esfera imanente das problematizações. Segundo pensamos, o filósofo aparece na Grécia como o herdeiro legítimo das virtudes deste antigo mundo guerreiro nômade, por tudo o que ele representa em termos de enfrentamentos e valores.

Mas, para além do nomadismo na esfera grega, não podemos esquecer que o próprio homem era inicialmente um nômade, só se sedentarizando no período Neolítico. É claro que isso já faz demasiado tempo, mas foi certamente neste momento que ele deu seus primeiros passos rumo a um processo civilizatório que o levou, majoritariamente falando, a ser como ele é. E o que ele é, repetimos Deleuze aqui, é já uma forma de aprisionamento da vida. Afinal, a própria sedentarização é já, em si, um ato de contenção da natureza, dos fluxos vitais. Tudo começa a ser contido, as vidas, a terra, o tempo... Não demorou muito para o Estado fincar suas raízes e, com sua contenção máxima dos fluxos e sua inerente estratificação, a figura do "mais frio dos monstros frios", como dizia Nietzsche, chegou para ficar com sua maquinaria abstrata pesada e sua moral castradora. É isso que explica produção de corpos dóceis e submissos. O resto é história: lutas, consensos, guerras, acordos. Seguimos com a máquina do Estado, ora mais forte, ora mais fraca, mas sempre presente em nossas vidas como um Pai que nos vigia e controla. E o mais grave de tudo é que temos estado acuados entre um capitalismo feroz e a vigilância de um Estado forte.

Sem dúvida, é compreensível que o signo maior do sedentarismo, o Estado, esteja impresso em nós como uma tatuagem que não se consegue apagar facilmente, embora também não pareça menos verdadeiro que, bem profundamente, no âmago do homem, ele ainda traga algo do nômade quando suspira por liberdade, por ar puro, pois é a própria vida que se encontra encurralada na "forma-homem". É evidente que não se pretende retornar às origens primeiras; não se trata de romantizar ou idealizar a vida natural. Trata-se, no entanto, de compreender o que isso representou para o homem. Trocamos a liberdade pela segurança e proteção, mas não sem vigilância e punição. O mundo criado por nós é, sem dúvida, uma imensa gaiola e é a vida que jaz dentro dela, a vida dos homens e a de todos os outros seres. Tudo em nós 
se apresenta corrompido, primeiro por uma moral transcendente que torna a própria razão refém (e também um instrumento privilegiado) deste desejo de proteção e segurança máximos. E segundo, pelo niilismo que decorre do adoecimento da própria vida que se tornou servil.

Eis que era preciso implodir a própria da razão, e é o que Nietzsche fez (e que Artaud também fará em suas experimentações com a linguagem) para que o pensamento emergisse em toda a sua potência nômade, em toda sua força crítica e criadora. Mas é bom não esquecer que o pensamento não se opõe à razão no sentido de ser uma desrazão; o pensamento é um outro da própria razão, é quando os conceitos deixam de ser formas puras e vazias e adquirem movimento, penetrando assim nos devires da própria vida. Para nós, é falso pensar que existe alguma legítima aliança entre o nomadismo e o sedentarismo; tudo o que a máquina de guerra deseja é se infiltrar no aparelho do Estado e dele absorver o que precisa para sobreviver, mas nunca reforçando os seus signos e códigos. O problema é que a máquina de guerra vive sendo apoderada, pelo déspota, o de fora e o de dentro, aquele que também nos habita, pela interiorização dos poderes em nós.

E aqui começa a ficar mais claro o sentido vital do corpo sem órgãos, que está intrinsecamente ligado à produção desta máquina de guerra e na luta contínua contra a sua apoderação. Sim, o pensamento precisa estar sempre vigilante, não pode dormir nem delirar excessivamente. É preciso que se entenda que o CsO é uma busca de desconstrução ativa do corpo, e isso quer dizer simplesmente, como dissemos na introdução, rearranjá-lo em nova configuração, ou seja, fazê-lo recuperar sua mobilidade, seus devires, suas linhas intensivas, sua plasticidade. Como dissemos antes, não se trata da produção de perversões ou de apologia a drogas e a delírios sexuais. Trata-se bem mais, em Deleuze e Guattari, de uma necessidade de reconectar o corpo ao seu meio vital, à vida pulsante que nos abarca a todos, nos reconectar a outros corpos, a outros devires. Retirá-lo da sua inércia e fixidez, mas também das falsas concepções psicanalíticas que o condenam a ser uma vítima do processo civilizatório ao invés de fazê-lo recriar-se.

É claro que toda desconstrução é perigosa, e mais ainda porque nem toda desconstrução é realmente ativa e revolucionária por si 
mesma. A desconstrução ativa já é a própria transmutação em andamento, é a própria produção da máquina de guerra, ao passo que a desconstrução, quando reativa e niilista, termina com o esvaziamento do desejo e da própria vida. É a distinção que Deleuze e Guattari fazem entre os $\mathrm{CsO}$ plenos e os $\mathrm{CsO}$ esvaziados. Não é por outra razão que eles mesmos se perguntam: "por que este desfile lúgubre de corpos costurados, vitrificados, catatonizados, aspirados, posto que o CsO é também pleno de alegria, de êxtase, de dança?" (2012, vol. 3, p. 13). "Por que passar por estes exemplos?" Por que tratar do $\mathrm{CsO}$ dos masoquistas, dos hipocondríacos, dos esquizofrênicos, dos drogados, etc., por que tratar "de corpos esvaziados ao invés de plenos", quando a ideia é propor a produção de corpos intensivos e poderosos para o próprio desejo?

É porque é preciso mostrar exatamente exemplos daqueles que acabam levando a guerra contra o organismo a um ponto crítico, onde, na expressão radical do desejo, é o próprio desejo que é destruído; é a própria vida que termina por não se sustentar. Como dizem Deleuze e Guattari, “o pior não é permanecer estratificado - organizado, significado, sujeitado - mas precipitar os estratos numa queda suicida ou demente que os faz recair sobre nós ainda mais pesados do que nunca" (2012, v.3, p. 27). Neste caso, é o próprio devir revolucionário que é capturado por forças negativas e, assim, enquanto se pensa buscar a liberdade, se está sendo cada vez mais arrastado para a morte.

O que ocorre é que tais corpos já são o efeito de uma mutilação da vida; eles são o resultado de uma moral tirânica que faz cindir o próprio ser, enquanto encurrala o desejo de todas as maneiras, até que ele seja vivido como um segredo sujo e pecaminoso. Como diz Nietzsche, a moral corrompe a vida. É porque o desejo não é vivido naturalmente que ele se perverte e destrói o corpo ao invés de potencializá-lo. É assim que a moral tem criado homens partidos, consciências tristes ou hipócritas; e o fato é que ainda não saímos da moral enquanto não criamos novas maneiras de ser, de sentir e de viver.

Quem fala muito adequadamente contra a moral, que cria corpos e almas partidas é Michel Onfray que, de resto, não entendeu bem a 
ideia do $\mathrm{CsO}$ de Deleuze e Guattari ${ }^{6}$. Não se trata de um corpo abstrato, nem metafísico, mas isso o levou a pensar nos dois corpos da moral que, em muito, elucida como vivem, na prática, os homens em geral. Ele não se equivoca quando discorre sobre a hipócrita moral que nos constitui como seres partidos, com seus dois corpos vivendo num eterno conflito e se destruindo mutuamente: um corpo social e um corpo desejante. Mas se trata aqui do homem da moral e não do CsO. Sim, por trás da moral e dos bons costumes estaria a perversão e os delírios como seu subsolo aceito e até desejado. É uma cisão que se opera aqui no próprio desejo e no próprio ser: vive-se de um lado com um corpo ordenado, dócil, que respeita as regras do mundo, ou seja, o seu teatro das formas, das práticas sociais; e, do outro lado, vive-se o desejo como algo sujo, a noite escura, o corpo do pecado, que pode a qualquer instante dissolver o outro mundo. Vive-se partido, esfacelado, sem maneiras de conciliar-se consigo mesmo. Essa análise é perfeita, mas repetimos que o $\mathrm{CsO}$ pleno e revolucionário é outra coisa.

É que o corpo sem órgãos é exatamente o fim desta cisão; não se constrói um $\mathrm{CsO}$ para si se não se ultrapassa esse corte. É porque o desejo, na moral, é vivido como pecado que ele produz sempre uma consciência culpada e enfraquecida - o que só aumenta o desespero do corpo e também seus delírios. O que acontece é que o próprio corpo, nesta cisão, perde exatamente seu poder de existir plenamente. E é porque a vida se torna pesada demais que a única saída consiste em aliviar o desespero. Eis porque é preciso criar um corpo talhado para a guerra, um corpo capaz de lutar contra as pressões e tiranias deste mundo; um corpo liberto do "pecado", mas do pecado que se comete contra a vida.

$\mathrm{E}$ isso que quer dizer o $\mathrm{CsO}$. "Encontre seu corpo sem órgãos, saiba fazê-lo, é uma questão de vida ou de morte, de juventude e de velhice, de tristeza e de alegria. É aí que tudo se decide" (DELEUZE e

6 Michel Onfray, de fato, não entendeu o conceito de Cs0 (coisa, aliás, que ele próprio enuncia claramente), a despeito dos grandes trabalhos que têm feito para desmitificar alguns ídolos, dentre eles, o próprio Freud, e, consequentemente, a psicanálise. Ele 0 entendeu como um duplo metafísico, imaterial, a despeito de produzir uma crítica interessante sobre a existência dos dois corpos da moral, ou seja, a ideia do homem cindido, que vive o desejo como sujo e pecaminoso. Sobre este ponto, cf. "Le totem n'est pas tabou" in Le magnétisme des solstices, cap. 29.

Rev. Filos., Aurora, Curitiba, v. 29, n. 46, p. 285-305, jan./abr. 2017 
GUATTARI, 2012, v.3, p. 13). Sem dúvida, trata-se de uma questão de vida, ou antes, de potência de vida. Não se trata de estabelecer novos juízos universais, mas de entender o que serve ou não para a produção real da existência. É preciso que o $\mathrm{CsO}$ seja uma resposta ao corpo que grita, à vida que não pode mais, ou seja, que ele represente a libertação da vida que foi encurralada em nós desde a mais tenra infância, e não a sua destruição.

Sim, o que precisa ficar claro é que, ao contrário do que parece, os corpos mais profundamente desesperados pelo prazer, não são os que vivem o desejo na sua máxima potência. Em geral, o que lhes falta, é o próprio desejo, ou antes, a alegria do desejo, que não se confunde com a genitalidade ou não se esgota nela, mas é antes produção de vida, produção da própria vida. É porque o desejo esvaziou-se no desespero que se vai cada vez mais fundo numa busca que não é a de um objeto (não é falta de um objeto), mas a do próprio desejo roubado. E vai-se tão fundo aí que se destrói o corpo, destrói a própria vida que se desejava libertar. Eis que uma frase de Nietzsche que resume bem o desespero pelas alegrias roubadas: "A mãe da devassidão não é a alegria, mas a ausência de alegria" (NIETZSCHE, 1902, I, 77)7.

É aqui que Espinosa e, para nós, também Nietzsche, tornam-se fundamentais para a compreensão mais precisa do $\mathrm{CsO}$ como produção de uma máquina de guerra em prol da vida. Não se trata de desejo enquanto sexualidade apenas. $\mathrm{O} \mathrm{CsO}$, como dissemos, não se reduz ao âmbito sexual, mesmo que seja aí que ele se expresse de modo mais visceral. O CsO é o corpo do devir, ou o corpo que devém, é o corpo intensivo que subjaz no corpo extenso como seu elemento genético, como sua esfera de potencialidades e forças. Desejo é vida. Vida é desejo. Isso quer dizer que desejo é produção, produção de vida, de mundos, de ideias, de valores, de corpos, de prazer. "É preciso libertar a vida", dizia Nietzsche, e isso quer dizer simplesmente que é preciso libertar a vida que foi aprisionada nas vísceras do homem, e pelo próprio homem.

7 Tradução da autora. 
Mas, como dissemos no início, e ao contrário do que muitos esperariam, Deleuze e Guattari são os primeiros a ressaltarem o valor da prudência (a virtude capital para Aristóteles, também chamada de sabedoria) para a produção do $\mathrm{CsO}$. $\mathrm{Na}$ verdade, eles deixam claro que, sem prudência, não se cria um $\mathrm{CsO}$ pleno, revolucionário. A prudência, como sabemos, é o próprio agir deliberado, refletido, pensado. Ter prudência significa ter cautela, medida, e isso implica em saber avançar e recuar, em saber escolher o melhor para si, implica em expansão, mas também em contenção, ou seja, implica no governo de si. É por isso que defendemos aqui que, ainda que se trate da produção do corpo, o corpo não pode ser pensado como algo desconectado do pensamento. Porque ter prudência, no fundo, consiste simplesmente em saber escolher o que nos fortalece e o que nos enfraquece, como nos ensina a Ética de Espinosa. Afinal, o que fortalece o corpo, fortalece o espírito e vice-versa. Sabemos que algo vai muito mal em nossos desejos quando eles nos despotencializam e nos matam paulatinamente ao invés de nos tornar mais vigorosos e plenos para a vida.

Em outras palavras, não se cria um $\mathrm{CsO}$ às escuras ou em delírio total. Ele é obra também do pensamento. E a questão fundamental agora é: como pensar a prudência num pensamento que entende o Eu e a consciência como instrumentos de uma moral que os produz exatamente para interiorizar os poderes em nós? A resposta é: será preciso operar, em nós mesmos, uma despersonalização, uma "desinteriorização", mas isso está longe de querer dizer defesa da loucura ou algum tipo de irracionalismo; e menos ainda se trata de uma entrega pura aos desejos. Ao contrário, é o pensamento que é a chave da questão aqui, esse é o grande segredo do $\mathrm{CsO}$.

Isso porque, numa perspectiva imanente, toda experimentação do corpo é já uma experimentação do pensamento. Não é sem motivos, repetimos, que Deleuze e Guattari elegem a Ética de Espinosa como o grande livro do corpo sem órgãos. Para Espinosa, como sabemos, "a ordem das ações e das paixões do nosso corpo vai, por natureza, de par, com a ordem das ações e paixões do espírito" (2009, III, 2, esc.). Não existe um corte ontológico aqui; não existe nenhuma eminência aqui de um sobre o outro, nenhuma transcendência. "Trata-se, isso 
sim, de adquirir um conhecimento das potências do corpo para descobrir paralelamente as potências do espírito que escapam à consciência". (DELEUZE, 1986, p. 79).

Não se sabe "o que pode um corpo" (ESPINOSA, 2009, III, p. 2 esc.), já afirmava Espinosa, mas isso quer dizer apenas que a consciência é ignorante sobre sua potência; e o mesmo vale para as potências do pensamento, a verdadeira máquina de guerra. Aqui, é a própria consciência que é entendida como impotente para conhecer as conexões do corpo e também das ideias. Eis porque ela moraliza, cria ficções, já que ela só conhece os efeitos e nunca as causas das coisas (DELEUZE, 1986, p. 27-29). Mas o que se dá no corpo se dá no espírito, e vice-versa. Não existem encontros puramente físicos ou puramente espirituais. Libertar um é já libertar o outro. Só assim é possível falar em criação real de novos modos de ser, de viver, de amar, novos modos de existir.

Mas há que se ter cautela também quando se trata de desconstruir as noções de interioridade, de Eu e de consciência em benefício da singularidade. Não se trata jamais também de entender essa desconstrução como negação de uma coesão interna. É claro que tais noções são signos e instrumentos desta moral transcendente e castradora, mas é preciso entender que o processo de dessubjetivações do Eu não significa mergulhar no caos ou na loucura. Dissolver o Eu implica num duplo movimento: o de sua desconstrução e o de sua reconstrução enquanto singularidade.

Não nos enganemos aqui também: o pensamento depende de uma coesão de forças, tanto quanto o corpo. Não se pode entender a guerra contra o Eu ou a consciência como uma cisão do ser. Os seres cindidos, partidos, são os da moral; o CsO é mesmo outra coisa. Mesmo Artaud desejava fazer o pensamento coincidir com o corpo, ou, simplesmente, queria um corpo pensante. Desconstruir o Eu é também chegar ao seu cerne, ou melhor, no cerne do corpo, para descobrir exatamente o que ele é sem as confusões da consciência: e ele é uma polifonia, ele é uma multiplicidade. Não existe uma unidade a priori; ela é sempre a posteriori, e sem nunca deixar de ser uma multiplicidade. Afinal, o uno é o múltiplo, como já dizia Nietzsche (1987, p. 46), embora isso não queira dizer, insistimos aqui, que não exista uma coesão 
de linhas intensivas que chamamos de Eu. Afinal, não foi o próprio Nietzsche (que mesmo criticando as ideias de Eu e de interioridade), sempre falou de si de um modo poderoso e afirmativo? Como não sentir a força descomunal daquele que fala em seu próprio nome? Isso é ser singular. E é disso que o próprio Deleuze nos fala. Ele nos fala deste poder de Nietzsche de nos ensinar a falar em nome próprio ${ }^{8}$. Não se trata de um Eu profundo, mas de um ser que passou pelo mais severo exercício de despersonalização, se abrindo às multiplicidades e intensidades, para, então, se constituir de um modo novo. Sim, singularizar-se é já o efeito de uma transmutação, de uma reconstrução, de um rearranjo das forças. Poderíamos, então, dizer (e por que não?) que se trata de um Eu nômade e cambiante.

Enfim, é da produção da singularidade que falamos aqui. E esta é, para nós, a verdadeira tarefa revolucionária; pois é na afirmação da singularidade que se supera a fixidez da identidade e a consciência como instância moral do homem partido. Sim, é de vida que se trata aqui, e vida é criação, é potência, é arte, em última instância. E, afinal, é o próprio Deleuze quem se apresenta como um vitalista (1992, p. 228), o que está longe de querer dizer que ele tem uma noção de vida ingênua ou metafísica. Ao contrário, como Nietzsche, Deleuze pensa a vida como uma potência neutra, nem boa nem má, indeterminada e singular em sua expressão mais radical.

Ser um vitalista é isso: é apostar na existência, é apostar na vida. É produzir a própria existência a partir de operações que se realizam na mais pura imanência e potência do ser. Sim, a construção de um corpo sem órgãos é uma questão de potência de vida e, fora de qualquer aspecto moral, significa simplesmente: criar um corpo mais forte, mais resistente e mais alegre para a própria vida. A vida pode não ter um sentido superior, pode até ser absurda como dizem os existencialistas, mas nem por isso é algo sem valor ou importância. Pelo contrário, a vida é o palco onde tudo acontece. Eis porque aqui não se brinca. É a vida mesma que está em jogo.

8 Deleuze aborda este tema em uma carta dirigida a Michel Cressole. Cf. Conversações, p.11. 


\section{Referências}

BERGSON, H. O pensamento e o movente. São Paulo: Martins Fontes. 2006.

DELEUZE, G. Conversações. São Paulo: Editora 34, 1992.

DELEUZE, G. Espinoza e os signos. Porto: Rés Editora, 1986.

DELEUZE, G. Foucault, Lisboa: Vega, 1987.

DELEUZE, G. Pensamento Nômade in Nietzsche hoje? São Paulo: Brasiliense, 1985.

DELEUZE, G.; GUATTARI, F. O anti-Édipo - Capitalismo e esquizofrenia. Lisboa: Assírio \& Alvim, 2004.

DELEUZE, G.; GUATTARI, F. Mil platôs (5 volumes). São Paulo: Editora 34, 2012.

ESPINOSA, B. Ética. Belo Horizonte: Autêntica, 2009.

FOUCAULT, M. Vigiar e punir. Petrópolis: Vozes, 1988.

NIETZSCHE, F. A filosofia na idade trágica dos gregos. Lisboa: Edições 70, 1987.

NIETZSCHE, F. Le voyageur et son ombre. Paris: Mercure de France, 1902.

NIETZSCHE, F. Genealogia da moral. São Paulo: Companhia das Letras, 2009.

NIETZSCHE, F. Obras incompletas. São Paulo: Nova Cultural, 1999.

ONFRAY, M. Le magnétisme des solstices. Paris: Flammarion, 2013.

Recebido: 08/09/2016

Received: 09/08/2016

Aprovado: 10/10/2016

Approved: 10/10/2016 
